\title{
The Relationship between Critical Thinking, Self-regulation, and Teaching Style Preferences among EFL Teachers: A Path Analysis Approach
}

\author{
Tahereh Heydarnejad ${ }^{1}$, Azar Hosseini Fatemi², Behzad Ghonsooly ${ }^{2}$ \\ ${ }^{1}$ University of Gonabad \\ ${ }^{2}$ Ferdowsi University of Mashhad
}

\begin{abstract}
Correspondence concerning this article should be addressed to Tahereh Heydarnejad, University of Gonabad, Department of English Language, Faculty of Literature and Humanities, University of Gonabad,Khorasan Razavi Province, Gonabad, Iran. Email: t.heydarnejad88@yahoo.com
\end{abstract}

\begin{abstract}
Teachers are world makers. They can change the thinking, attitudes, and lives of their students. Thus, it is essential to study the factors that foster teachers' competency. Critical thinking, selfregulation, and teaching style are some of the factors influencing the effectiveness of teachers. In line with this argument, the present study delved into the possible impact of critical thinking abilities and self-regulatory strategies of English as a foreign language (EFL) teachers on their teaching style preferences. The possible influence of critical thinking abilities on teacher selfregulation was also studied. To do this, Watson-Glaser's Critical Thinking Appraisal (Form 1), the Teacher Self-Regulation Scale (TSRS), and Grasha's Teaching Style Inventory (TSI) were administered to $320 \mathrm{EFL}$ teachers who were teaching at different private language institutions in Iran. A path analysis was utilized to ponder their causal relationships. The findings indicated that teachers with higher critical thinking abilities and self-regulatory skills tend to implement learner- centered styles (namely, Facilitator and Delegator) while teachers with lower critical thinking abilities and self-regulatory skills tend to do the opposite. Moreover, the significant effects of critical thinking on teacher self-regulation were determined. The implications of this study may open up new perspectives into successful pedagogy for policymakers, curriculum designers, and teachers.
\end{abstract}

Keywords: critical thinking, self-regulation, teaching styles, EFL teachers, path analysis

\section{Introduction}

The era of technology and information uncovers new challenges every day, which calls for expanding novel approaches to achieve efficient teaching and instruction. These changing conditions push educational capabilities to cultivate Critical Thinking (CT) as a higher-order thinking skill. That is, CT ensures betterthinking capacities in EFL teachers and enables them to evaluate and analyze (Zhang, Yuan, \& He, 2020) before drawing conclusions or making a judgment. As a result, with better decisions, the future is more secure and successful.

Dewey (1933), who is referred to as the father of modern critical thinking, considered CT to be an active lens that helps to make inferences based on the existing evidence. In other words, CT puts forward a royal road to thinking (Ghanizadeh \& Heydarnejad, 2015). That means CT, along with sophisticated thinking skills, takes individuals from the surface layer of meaning into the deeper one involving inferences (Renner, 1996), which is necessary for insightful education. CT also offers a standard of intellectual excellence that is essential for people's academic and social lives (Scriven \& Paul, 2004). Therefore, by helping teachers to cultivate CT, the educational system and society are sowing the seeds of a generation with better thinking capabilities. Hence, it is part of the priorities of a proper instruction to provide efficient room for the students to think deeply and share their thoughts with their peers. This goal is not reachable unless the teachers are critical thinkers themselves.

CT can also be defined as a deliberate and self-regulatory judgment about one's actions and thoughts (Giancarlo \& Facione, 2001). Self-regulation reflects the utilization of self-assessment and self-awareness techniques 
(Zimmerman \& Risemberg, 1997) with a profound influence on professional success (Davis \& Gray, 2007). Teachers play a pivotal role in effective instruction; to that end, they should monitor and evaluate their ideas, behaviors, and other self- regulatory factors related to educational contexts (Dembo, 2001; Peel, 2020). Selfregulation provides a golden chance for teachers to define objectives, act decisively, and modify their teaching accordingly (Karimnia \& Mohammadi, 2019; Yesim, Sungur, \& Uzuntiryaki, 2009). Key to this discussion, Paris and Winograd (1999) claimed that self-regulation enables teachers to better adjust to the needs of the students as well as evaluate teaching and learning strategies deeply. Tying together CT and self-regulation, society can take a step toward insightful and practical instruction.

Another crucial aspect of successful instruction is teachers' adopted teaching styles, which represent teachers' attitudes, approaches, and practices in teaching (Cooper, 2001; Tavakoli \& Karimnia, 2017). Moreover, Jarvis (2004) stipulated that teaching style specifies teachers' perceptions and attitudes toward all the parts related to teaching and learning. In other words, teaching styles are general principles as well as educational and management strategies for classroom instruction. As individuals learn differently, there are different teaching styles as well.

Successful teachers are those who are aware of students' different learning styles and attempt to implement suitable teaching styles to motivate students and increase their engagement in learning. To achieve these objectives, teachers should be equipped with knowledge and skills to evaluate and modify themselves, and consequently design instruction in the best way. Facilitating knowledge and skills, especially with higher-order thinking skills (Zhang, Yuan, \& He, 2020), is not an easy task and sheds light on some avenues for further research. Considering the crucial role of teaching style, this study sought to explore the possible influence of $\mathrm{CT}$ and self-regulation on successful styles of teaching.

\section{Background}

In the following sections, the relevant literature on critical thinking, self-regulation, and teaching style is briefly reviewed.

\section{Critical Thinking}

About two thousand years ago, the concept of critical thinking was put forward by Socrates, who emphasized reasoning, questioning, analyzing, and evaluating as the basis of every judgment. Reviewing the existing literature on CT reveals no agreement upon a unified definition (Fasko, 2003; Fisher, 2001; Halanon, 1995; Minnich, 1990). In Ennis's words (1996), CT is an ongoing evaluation of ideas to make inferences based on the available evidence. Similarly, Ivie (2001) describes critical thinking in terms of reflective practices, which connects early assumptions to justified conclusions in a logical way. An indisputable definition of CT is proposed by The American Philosophical Association, which characterized CT as deliberate and self-regulatory decision making via verification, inquiry, appraisal, and inference (Giancarlo \& Facione, 2001).

Although there are no agreed-upon definitions of CT, a considerable body of literature highlights the significant role of CT in all aspects of life, especially in achieving academic objectives (Facione \& Facione, 1996). As Dewey (1933) noted, the core aim of education is learning to think; to reach this goal, students need to learn how to use CT strategies in the academic domain (Keeley, Holland, \& Watson, 2005). Key to this discussion, Elder and Paul (2003) emphasized the crucial role of CT in converting learners into active questioners. CT is not an inborn ability (Ghanizadeh \& Heydarnejad, 2015); thus, it should be created and shaped by teachers as the drivers of education vehicles who are responsible for providing and practicing deep comprehension (Heydarnejad, Ebrahimi, \& Najjari, 2018).

The capability to think critically and reflectively is related to a teacher's intellect and experience (Dewey, 1933). In this regard, Jenkins (1998) stressed that CT develops teacher competencies and turns a novice teacher into an autonomous one. According to Reynolds (1992), competent teachers analyze their activities using higher-order thinking skills (CT and reflective thinking). In a similar way, Mayfield (2001) stressed that a critically reflective teacher raises students' awareness of critical thinking by engaging them in critical thinking activities. Thus, the evidence is overwhelming that teachers need to expand their knowledge and skills in CT. 
Taking these standpoints in mind, critical thinking skills and their positive effects on educational achievement in EFL settings (among many others) provide a fertile field in which to undertake educational research. For instance, in a recent study by Bobkina and Stefanova (2016), the benefits of developing a model of teaching critical thinking skills in the EFL classroom is investigated. They concluded that critical thinking skills enable learners to create their own reflective learning styles. In another study, Kavanoz and Akbas (2017) inferred that EFL teachers are capable of practicing critical thinking in their classrooms if they develop an adequate knowledge of critical thinking. Similarly, Zhang et al. (2020) referred to EFL teachers' narrow understanding of CT as well as the gap between EFL teachers' attitudes toward CT and their actual class activities as the reasons for not successfully implementing CT in EFL classes.

\section{Self-regulation}

Self-regulation simply outlines self-supporting thoughts, sensations, and behaviors that are premeditated and adjusted to achieve personal objectives (Zimmerman, 2000). In the learning context, self-regulation refers to the active involvement of students in the goal setting, self- monitoring, and self-evaluation of their learning (Pintrich, 2000). In the teaching domain, self- regulation reflects teachers' strategies to regulate and manage their activities (Yesim et al., 2009) and emotions (Heydarnejad, Hosseini Fatemi, \& Ghonsooli, 2017b). All in all, theories on student self-regulation were generalized to theories and principles on teacher self-regulation.

Self-regulation and self-control seem to have similar meanings, but they are different. While self- regulation has to do with impeding strong impulses, self-regulation lessens the frequency and strength of strong impulses by controlling stress-load and recovery (Shanker, 2016). To get more specific, self-regulation manages selfcontrol. The notion of teacher self-regulation can also be discussed from personal and social viewpoints (Delfino, Dettori, \& Persico, 2010). From a particular viewpoint, teachers armed with self-regularity strategies evaluate and monitor their progress; they adjust their actions to achieve the desired outcome. From the social perspective, self-regulation helps teachers adapt themselves to students' needs and the fast speed of technology. Self-regulation covers a wide range of behaviors from minute-to-minute choices to the larger, more significant decisions that can have a substantial impact on whether people meet their goals.

Key to this discussion, the association between Iranian EFL teachers' self-regulation and self- resiliency was explored in a study by Partovi and Tafazoli (2016). They found that Iranian EFL teachers who adopted more self-regulatory strategies were more resilient. In a similar manner, Monshi Toussi and Ghanizadeh (2012) found a significant relationship between teachers' self- regulation and internal locus of control. They also concluded that EFL teacher self-efficacy had no significant impact on the relationship between self-regulation and locus of control. In another recent study, a positive relationship between teachers' reflective practices and their selfregulation was discovered (Pazhoman \& Sarkhosh, 2019).

Overall, leafing through the empirical studies conducted on self-regulation revealed that the majority of studies in this realm were related to the learners (Alvi \& Gillies, 2020; Dignath \& Büttner, 2018; Peel, 2020). Those that drew attention to teacher self-regulation focused on the self-regulatory practices of teachers as being learners or considered teachers as the responsible ones to learn self-regulatory strategies for the sake of transferring them to their own learners (Dembo, 2001; Peel, 2019; Randi, 2004; Yesim et al., 2009). Thus, teacher selfregulation is still in its infancy and requires a more insightful analysis.

\section{Teaching Style}

Individuals are different due to their distinctive style of thinking, preferences, and ways of doing things that influence their behavior (Heydarnejad, Hosseini Fatemi, \& Ghonsooli, 2017a). Teachers are not an exception; their attitudes toward teaching and the strategies that they employ are their distinctive teaching style (Grasha, 2002). In other words, teaching style is teachers' personal preferences, knowledge, and beliefs that influence how they present information to their learners and receive feedback (Kaplan \& Kies, 1995). In fact, teachers, like students, could employ many teaching and management strategies for classroom instruction, which are due to different personal attitudes, inspirations, ways of thinking, and social background (Vaughn \& Baker, 2001). As Grasha (1996) put it, these styles are like colors on an artist's palette, which converge into various clusters and make up the distinctive ways teachers design instructional settings.

Studies on teaching styles emerged in the 1970s (Biggs, 2001). An overwhelming number of classifications can be found in the literature that portrays different teaching styles. The following are some of these classifications: 
Direct style-Indirect style (didactic-student-centered) by Flanders (1970), Formal style-Informal style by Bennett, Jordan, Long, and Wade (1976), Open style- Traditional style by Solomon and Kendall (1979), and Intellectual Excitement style-Interpersonal Rapport style by Lowman (1995). In the current research, Grasha's model (1994, p.143) was applied due to its integrity and comprehensiveness. This model identifies styles of teaching as:

1. Expert: A teacher with expert style strives to maintain status as an expert among learners by presenting detailed knowledge.

2. Formal Authority: A teacher who teaches by formal authority style supervises learners critically and generally concentrates on the content. This style of teaching does not emphasize the student's participation, needs, and affective factors.

3. Personal Model: A teacher who implements personal model style expects the learners to copy his/her attitudes and approaches as the central model in the class.

4. Facilitator: A facilitator teacher focuses on self-learning and self-discovery in the class. Independent and responsible learners are the product of facilitator style of teaching.

5. Delegator style: A delegator teacher enhances autonomy and confidence in the learners. $\mathrm{He} / \mathrm{She}$ emphasizes group work and collaboration. Collaboration and peer to peer learning are the dominant goals in this style.

Expert, Formal Authority, and Personal Model styles are considered to be teacher-centered styles; whereas, Facilitator and Delegator styles correspond to student-centered styles. As Grasha (1994) put it, this classification originated from the traditional binary between teacher-centered and student-centered styles of teaching. The teacher-centered approach originated from the behaviorist theory, which claimed that changes in behavior are due to external stimuli (Skinner, 1974). Each teacher may adopt all these styles but to a varying extent. To ensure effective instruction, the teacher, as the center of the education, should challenge themselves to tailor their tutoring to different learners and in various educational contexts. Furthermore, educational and cultural backgrounds as well as teaching and learning experiences are influential in teaching style adaptation (Faruji, 2012; Nouraey \& Karimnia, 2016; Tavakoli \& Karimnia, 2017).

A recent study dealt with the effects of teachers' gender, teaching experience, and brain dominance on their teaching style in the EFL context of Iran (Karimnia \& Mohammadi, 2019). Their findings implied that a teacher's gender makes a difference in the formality of their teaching style. Regarding the impact of teaching experience on teaching style, a significant difference between teachers with different teaching experience was concluded. However, no significant finding was reported with regard to the effects of brain dominance on teaching style.

The above-mentioned studies highlight the contributing effect of CT, self-regulation, and teaching style on teachers' practices and instructional behaviors; however, to the researchers' best knowledge no study has ever considered these variables in a single study. Moreover, few researchers have ever attended to some of these goals in an Iranian context. Henceforth, the current study is a response to the call for better understanding the association of EFL teachers' critical thinking with self- regulation and teaching style. Therefore, the following research questions are explored in the current investigation:

1. Does EFL teachers' critical thinking have any impact on their self-regulation?

2. Does EFL teachers' critical thinking have any impact on their teaching style preferences?

3. Does EFL teacher self-regulation have any impact on their teaching style preferences? Based on the research questions, the following null hypotheses could be formulated:

HO1. EFL teachers' critical thinking has no impact on their self-regulation.

HO2. EFL teachers' critical thinking has no impact on their teaching style preferences.

HO3. EFL teacher self-regulation has no impact on their teaching style preferences.

\section{Materials and Methods}

In this section, the methodological steps that were taken in conducting this study are introduced. First, it introduces the participants and a detailed account of the instrument used for the research purposes. Then, the procedure of the current study, which includes some information about data collection and data analysis, is presented. 


\section{Participants}

The participants of the present study were 320 EFL teachers teaching at intermediate to upper- intermediate levels at private language institutions in different cities of Iran. They were selected based on convenience sampling. Also, to ensure generalizability, it was attempted to include participants from both genders with varying groups of age and teaching experience. There were 123 male and 185 female teachers (twelve teachers did not specify their gender), 22 to 48 years old, and with 1-26 years of teaching experience. Most of them held an MA degree or a BAdegree in different branches of English studies: English literature (98), English teaching (123), English translation (48), and 25 teachers were Ph.D. candidates in English teaching. Moreover, those teachers who had majored in other fields of study had the necessary qualifications to teach English.

\section{Instruments}

A battery of three questionnaires was utilized in this study as follows:

- Watson-Glaser Critical Thinking Appraisal - Form A

- Teacher Self-Regulation Scale (TSRS)

- $\quad$ Grasha's Teaching Style Inventory (TSI)

\section{Watson-Glaser Critical Thinking Appraisal-Form A}

To juxtapose CT, the Watson-Glaser Critical Thinking Appraisal - Form A (1980) was employed. It includes five sections with 80 items, measuring the five aspects of CT based on Watson and Glaser's definition (1980): inference, recognizing of assumptions, making deductions, interpretation, and evaluation. Along with the face, content, construct, and criterion validity of this inventory, which were satisfactory, the test-retest reliability was reported $(\mathrm{r}=.81)$ by Watson and Glaser (2002). In the current research, the reliability of Watson-Glaser Critical Thinking Appraisal (Form A) estimated via Cronbach’s alpha was .871.

\section{Teacher Self-Regulation Scale (TSRS)}

The Teacher Self-Regulation Scale (TSRS) developed and validated by Yesim et al. (2009), was utilized to measure teacher self-regulation. The formation of this scale is according to the self- regulation model proposed by Zimmerman (2000), along with semi-structured interviews with pre- service and in-service teachers. It comprises 40 items and nine subscales in the following sequence: goal setting, intrinsic interest, performance goal orientation, mastery goal orientation, self- instruction, emotional control, self-evaluation, self-reaction, and help-seeking. This inventory is on a six-point Likert-type scale, ranging from 'strongly disagree' to 'strongly agree'. Moreover, on this scale, there is one item as a filter, added to the 40 items, and it was not assessed in the following analyses. In the current study, the estimated reliability of the TSRS was .883, which indicated acceptable reliability.

\section{Grasha's Teaching Style Inventory (TSI)}

For measuring teaching style preferences, Grasha’s Teaching Style Inventory (1996) was employed. It contained 40 items and was answered on a seven-point Likert-type scale. This inventory consists of five components as follows: expert, formal authority, personal model, facilitator, and delegator teaching style. The present study reported acceptable reliability for all sub-scales of the TSI ranged from .869 to .896 .

\section{Procedure}

This study was carried out in different Iranian private language institutions, over two semesters from January to December 2019. The EFL teachers received the Watson-Glaser Critical Thinking Appraisal (Form A), Teacher Self-regulation Scale (TSRS), and Grasha's Teaching Style Inventory (TSI) in English versions because all of them were experienced English users. The questionnaires were administered either in a paper-and-pencil format or through a web-based platform.

\section{Data Analysis}

The reliability of the questionnaires was checked by the use of Cronbach's alpha formula. The KolmogorovSmirnov Test was also used to test the normality distribution of the scores. Then, for the purpose of describing 
the collected data, descriptive statistics were applied. Finally, due to the normality of the data, Lisrel 8.8 was employed to analyze the data.

\section{Results}

The descriptive statistics of EFL teachers' teaching styles, self-regulation, and critical thinking are presented in the following table.

Table1

Descriptive statistics

\begin{tabular}{lccccc}
\hline \multicolumn{1}{c}{ Inventory } & $\mathbf{N}$ & Mean & Std. Deviation & Minimum & Maximum \\
\hline expert & 320 & 5.049 & 1.032 & 2.000 & 7 \\
formal.authority & 320 & 4.935 & 1.055 & 1.875 & 7 \\
personal.model & 320 & 5.010 & 1.022 & 2.000 & 7 \\
facilitator & 320 & 5.464 & 1.035 & 2.125 & 7 \\
delegator & 320 & 5.342 & 1.017 & 2.125 & 7 \\
TS & 320 & 5.160 & .935 & 2.150 & 6.900 \\
TSR & 320 & 4.729 & .809 & 2.225 & 5.900 \\
CT & 320 & 57.406 & 16.687 & 0 & 80.000 \\
\hline
\end{tabular}

As the results reported in Table 1 indicated, among teaching style subscales, Facilitator $(\mathrm{M}=5.464, \mathrm{SD}=1.035)$ and Delegator $(\mathrm{M}=5.342, \mathrm{SD}=1.017)$ got the highest mean scores. The other subscales got lower mean scores as follows: Expert $(\mathrm{M}=5.049, \mathrm{SD}=1.032)$, Personal Model $(\mathrm{M}=5.010, \mathrm{SD}=1.022)$, and Formal Authority $(\mathrm{M}=4.935$, $\mathrm{SD}=1.055)$. Table 1 also displays the following mean scores for teacher self-regulation and critical thinking respectively: $\mathrm{M}=4.729, \mathrm{M}=57.406$.

To employ statistical methods and make logical inferences based on the researcher's hypotheses, the most significant step is to choose an appropriate statistical method for the research study. To this aim, data distribution must be taken into consideration. To do so, the Kolmogorov-Smirnov Test was employed to check normality distributions of the variables.

Table 2

The results of $K-S$ Test

\begin{tabular}{lcc}
\hline \multicolumn{1}{c}{ Inventory } & Statistic & Sig \\
\hline expert & .158 & .200 \\
formal.authority & .204 & .095 \\
personal.model & .191 & .148 \\
facilitator & .231 & .052 \\
delegator & .189 & .156 \\
TS & .215 & .063 \\
TSR CT & .202 & .102 \\
& .228 & .055 \\
\hline
\end{tabular}

According to Table 2, the sig value for all the scales and their subcomponents was higher than

.05 , which suggests a normal distribution of the data. Thus, it can be implied that parametric methods could be employed for testing the related research hypotheses.

To this end, the LISREL 8.80 statistical package was used to test the structural relations in the proposed model. The fit indices examined to evaluate the model fit are as follows: the chi-square magnitude, the root mean square error of approximation (RMSEA), the comparative fit index (CFI), and the normed fit index (NFI). The acceptable criteria for fit indices are presented in Table 3. 
Table 3

Fit indices

\begin{tabular}{lcc}
\hline \multicolumn{1}{c}{ Model } & $\mathbf{1}$ & $\mathbf{2}$ \\
\hline Chi-square x2 & 421.67 & 3756.5 \\
Chi-square/df ratio & 2.83 & 2.75 \\
df & 149 & 1366 \\
RMSEA & .076 & .074 \\
CFI & .94 & .95 \\
NFI & .94 & .94 \\
\hline
\end{tabular}

\section{Figure 1}

Schematic representation of path coefficient values for the relationships among critical thinking, teacher selfregulation, and teaching styles (Model 1)

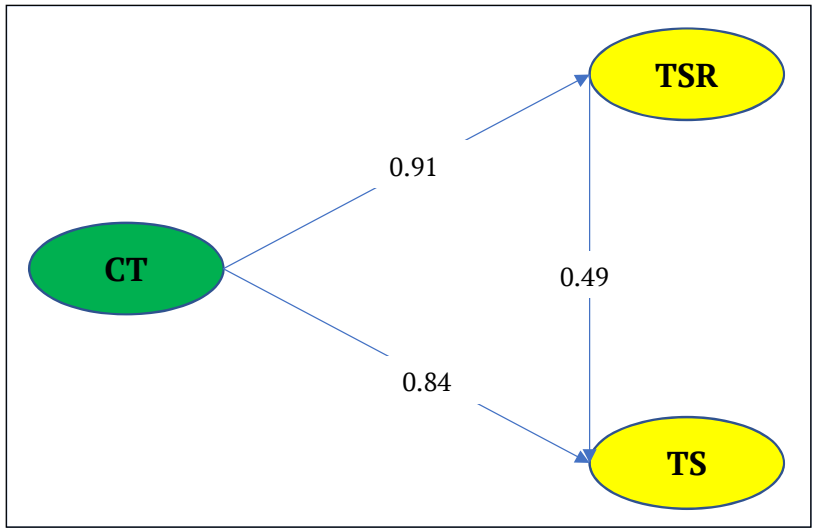

\section{Figure2}

T values for path coefficient significance (Model 1)

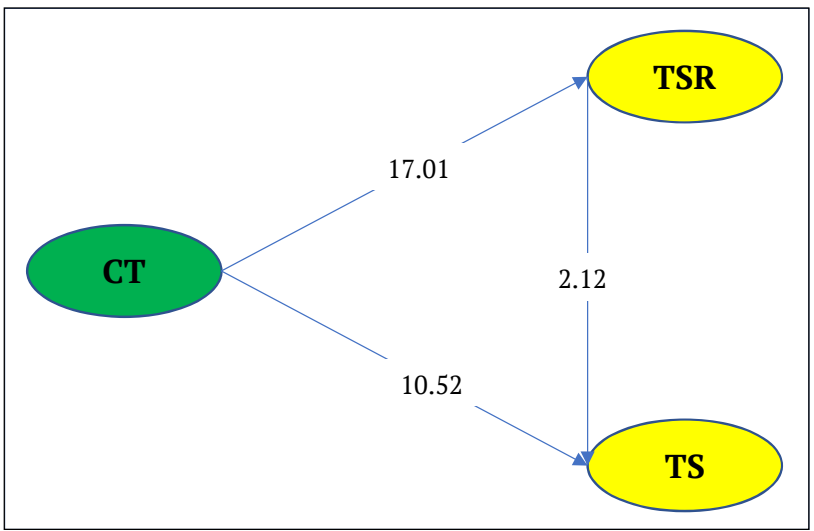

Based on Figure 1 and Figure 2 (Model 2), CT influences teacher self-regulation as well as teaching style, considering the $t$ value, which was greater than 1.96. In addition, Figure 1 and Figure 2 presented the influential role of CT in teaching style. That is to say, CT significantly and positively influences teacher self-regulation $(\beta=.91, t=17.01)$ and teaching style $(\beta=.84, t=10.52)$. The same is true for the influential role of teacher selfregulation in teaching style $(\beta=.49, \mathrm{t}=2.12)$. This schematic representation is shown in Figures 3 and 4 in a more detailed way.

Figures 3 and 4 (Model 2) illustrate the significant role of CT and teacher self-regulation on teaching subcomponents. According to these two figures, CT significantly and negatively affects Expert $(\beta=-.26, t=$ $-2.48)$, Formal Authority $(\beta=-.31, t=-4.59)$, and Personal Model $(\beta=-.22, \mathrm{t}=2.30)$. By contrast, it significantly and positively influences Facilitator $(\beta=.68, \mathrm{t}=8.04)$ and Delegator $(\beta=.64, \mathrm{t}=8.62)$. It is also worth highlighting that teacher self-regulation significantly and negatively influences Expert $(\beta=-.57, \mathrm{t}=-5.42)$, Formal Authority 
$(\beta=-.53, t=-5.55)$, and Personal Model $(\beta=-.30, t=-4.52)$. By contrast, it significantly and positively influences Facilitator $(\beta=.77, \mathrm{t}=9.74)$ and Delegator $(\beta=.64, \mathrm{t}=8.45)$.

\section{Figure 3}

Schematic representation of path coefficient values for the influential role of critical thinking and teacher selfregulation on teaching style' subscales (Model 2)

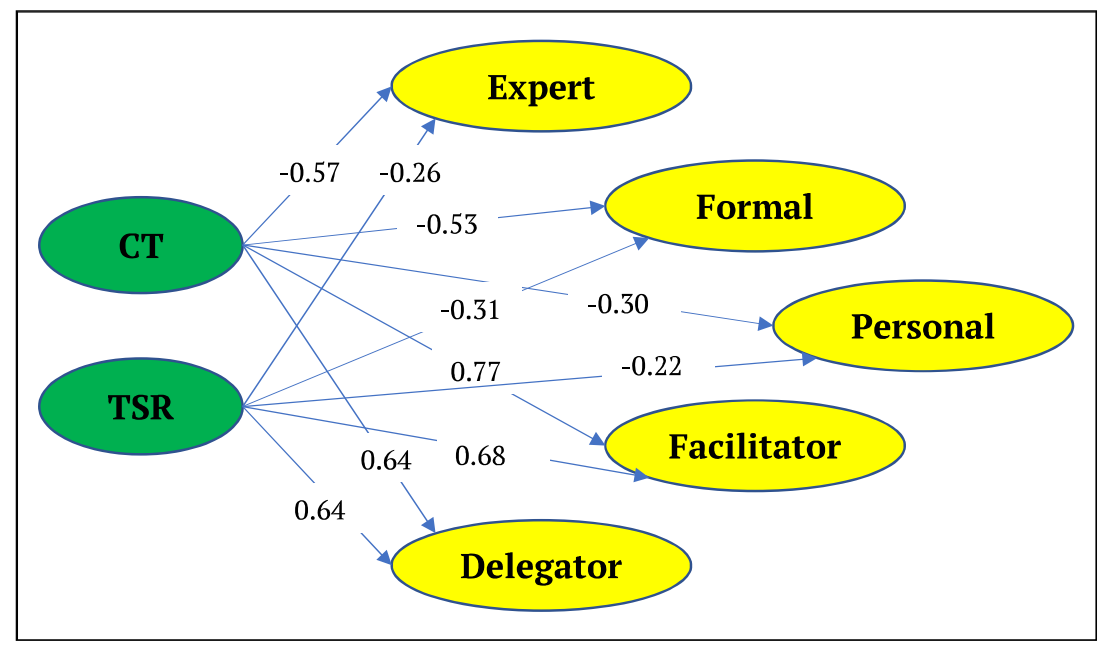

\section{Figure4}

T values for path coefficient significance (Model 2)

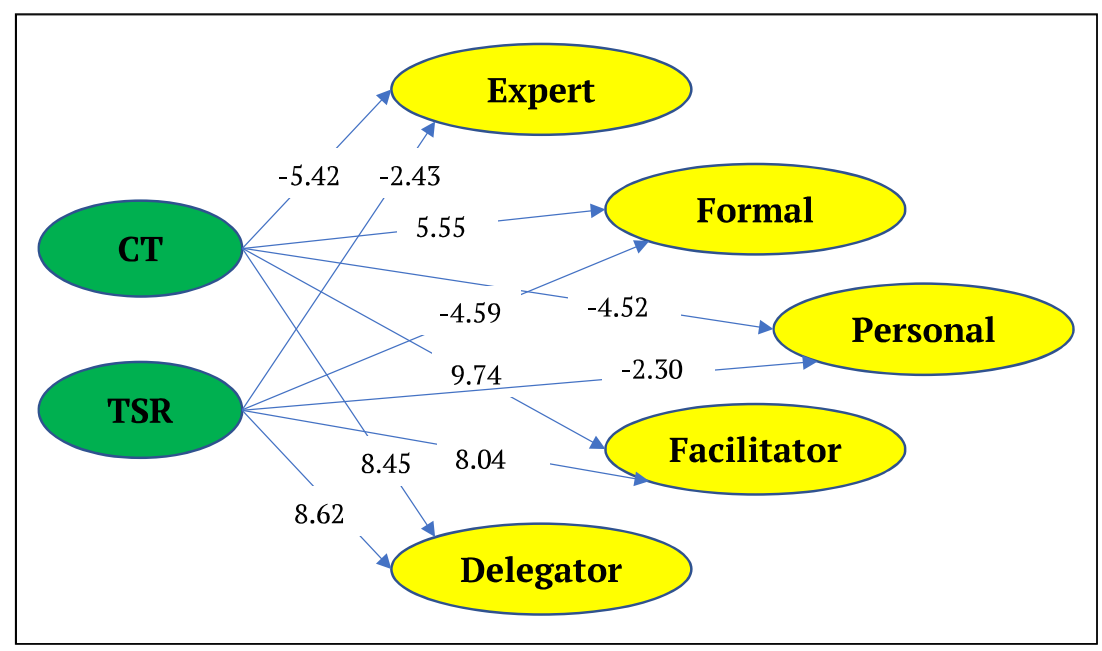

To determine the relationships among critical thinking, teacher self-regulation, and teaching style preferences, a Pearson product-moment correlation was run. 
Table 4

The correlation coefficients among critical thinking, teacher self-regulation, and teaching style

\begin{tabular}{|c|c|c|c|c|c|c|c|c|}
\hline & TS & TSR & CT & expert & formal & personal.model & facilitator & delegator \\
\hline TS & 1 & & & & & & & \\
\hline TSR & $.486^{*}$ & 1 & & & & & & \\
\hline CT & $.416^{*}$ & $.457 *$ & 1 & & & & & \\
\hline expert & $-.701^{*}$ & $-.401^{*}$ & $-.410^{*}$ & 1 & & & & \\
\hline formal.authority & $-.566^{*}$ & $-.386^{*}$ & $-.328 *$ & $.415^{*}$ & 1 & & & \\
\hline personal.model & $-.652 *$ & $-.351^{*}$ & $-.436^{*}$ & $.374^{*}$ & $.461^{*}$ & 1 & & \\
\hline facilitator & $.736^{*}$ & $.420^{*}$ & $.494^{*}$ & $-.438^{*}$ & $-.523^{*}$ & $-.415^{*}$ & 1 & \\
\hline delegator & $.713^{*}$ & $.411^{*}$ & $.479 *$ & $-.359 *$ & $-.429 *$ & $-.365^{*}$ & $.380 *$ & 1 \\
\hline
\end{tabular}

Note.* Correlation is significant at the 0.05 level (2-tailed).

As Table 4 presents, the relationships between critical thinking and teaching style subscales are as follows: correlated positively with Facilitator $(\mathrm{r}=.494, \mathrm{p}<.05)$ and Delegator $(\mathrm{r}=.479, \mathrm{p}<.05)$, but negatively with Personal Model $(\mathrm{r}=-.436, \mathrm{p}<.05)$, Expert $(\mathrm{r}=-.410, \mathrm{p}<.05)$, and Formal Authority $(\mathrm{r}=-.328, \mathrm{p}<.05)$. Furthermore, teacher self-regulation correlated negatively with Expert $(\mathrm{r}=-.401, \mathrm{p}<.05)$, Formal Authority $(\mathrm{r}=-.386, \mathrm{p}<.05)$, and Personal Model ( $\mathrm{r}=-.351, \mathrm{p}<.05)$. On the other hand, between self-regulation and Facilitator style of teaching $(\mathrm{r}=.420, \mathrm{p}<.05)$, and Delegator $(\mathrm{r}=.411, \mathrm{p}<.05)$, there are positive correlations.

\section{Discussion}

As mentioned earlier, the current study intended to shed some light on the possible influences of CT on teacher self-regulation and teaching style, as well as on the effects of teacher self-regulation on teaching style. As the results indicated, CT influences student-centered styles positively and significantly, while the impact of CT on teacher-centered styles is significantly negative. That is to say that the capability to reason, assess, and draw informed conclusions (the skills within the critical thinking realm) help teachers to apply a suitable style of teaching in their classes. Through the lens of CT, teachers are able to find the pros and cons of all procedures and approaches that they employ.

Actually, in the teacher-centered pedagogy, learners are passive and there is no margin for them to develop higher-order thinking skills and critical thinking abilities. This may be due to the fact that the teachers themselves do not reflect and analyze their behavior and actions; they are not critical thinkers or ignore the role of thinking critically. They just put up a set of rigid rules for students in the class to follow; also, group working, collaboration, learners' needs, individual differences, and affective factors are neglected in such classes. The teacher, as the authority in the class, prefers to give a lecture and present his/her knowledge and expertise to the students. In contrast, in the learner-centered pedagogy, raising autonomous and responsible students is a primary goal, which cannot be reached unless the learners have learned and practiced to think critically. Peer to peer interaction and cooperative learning comes to the fore (Condelli, Wrigley, \& Yoon, 2009), and indirect instruction, as well as productive learning, is possible via facilitator and delegator styles of teaching (Serin, 2018).

The findings of the current investigation confirm the findings of Zhang et al. (2020), who explored the interplay among critical thinking, teaching, and learning styles, and concluded that CT offers a golden opportunity for both teachers and learners to modify their teaching and learning styles. Moreover, the results of the present investigation are in accord with a recent qualitative study (Elias, Hamzah, \& Razak, 2019) indicating that higher-order thinking skills are vital tools that help learners become creative and reflective in a learnercentered context.

The other objective of this study sought to investigate the possible influence of CT on teacher self- regulation. As the findings displayed, CT has a significant positive effect on teacher self- regulation; therefore, the second null hypothesis was rejected. This means that teachers who are empowered with high-level CT skills nurture more self-regulatory strategies in their professional practice. In other words, the ability to think critically raises teachers' awareness and mindfulness in an ever-changing world. This outcome is in accord with 
Phan (2010), who presented a theoretical overview of CT and self-regulation in the educational context and inferred there was a close interrelationship between these two concepts. By the same token, Ghanizadeh (2011) confirmed the intertwined relationships between CT and self-regulation. Similarly, Gurcay and Ferah (2018) investigated the relationship between students' critical thinking and their metacognitive self- regulation. Their results indicated that CT correlated positively and significantly with metacognitive self- regulation. In the same vein, Vardi (2015) emphasizes the crucial role of critical thinking on the success of learners with the help of self-regulatory skills. The statistical findings of the present study also support Pintrich's view (2000) that the higher the teachers' involvement in thinking critically, the more they become capable administrators of self-regulatory skills in their actions.

The next objective of this study was to explore the possible effects of teacher self-regulation on the styles teachers adopt in their classes. The findings revealed a significantly influential role of teacher self-regulation on teaching styles; thus, the third null hypothesis was rejected. This finding seems plausible given that selfregulation acts as a magnifying glass trigger for self- awareness, self-reflection, self-monitoring, self-control, and self-evaluation. This self-aid device helps teachers monitor their actions and modify them, when necessary. Thus, they do not consider themselves as the formal authority and expert model in the class, but as a facilitator and delegator to reinforce productive and collaborative learning.

In a nutshell, a cursory look at the existing research concerning critical thinking (Ennis, 1996; Phan, 2010) and theoretical underpinnings on self-regulation (Pintrich, 1999, 2000; Schunk \& Zimmerman, 1994; Zimmerman, Bonner, \& Kovach, 1996), shows that it can be concluded that the two constructs are two sides of the same coin. Therefore, both of them are necessary for successful and effective pedagogy.

\section{Conclusion}

On the whole, this study was an attempt to contribute to the sparse knowledge on teaching style by investigating the relationship between critical thinking, self-regulation, and teaching style preferences among EFL teachers. The findings of the current study illuminated the contribution of CT and teacher self-regulation to the cultivation of learner-centered pedagogy, especially in the EFL teaching context. Furthermore, the benefit of CT for the enhancement of self-regulatory activities was highlighted. The implication is that EFL teachers armed with self-regulatory strategies and critical thinking skills prefer student-centered styles of teaching that enhance the quality of instruction. That is, being empowered by CT and self-regulatory strategies, teachers are capable of breaking the barrier of considering themselves as the dominant authority in the class without any room for student engagement and collaboration. Thus, employing this implication in the pre-service and inservice educational programs may lay the foundations for effective teaching and, consequently, effective learning. This research also hints at some useful implications for policymakers, teachers, and researchers.

Further studies are required to adopt mixed-method approaches and to triangulate data by means of employing other instruments such as class observations and focused interviews. More studies are also suggested to investigate the direction and the strength of the relations between the variables and their subcomponents via structural equation modelling (SEM).

\section{Conflict of interests}

The authors declare that they have no conflict of interest.

\section{References}

Alvi, E., \& Gillies, R.M. (2020). Promoting self-regulated learning through experiential learning in the early years of school: A qualitative case study. European Journal of Teacher Education, 44(2),135-157. https://doi.or $\mathrm{g} / 10.1080 / 02619768.2020 .1728739$.

Bennett, N., Jordan, J., Long, G., \& Wade. B. (1976). Teaching Styles and pupil progress. Open Books Publishing Limited. 
Biggs, J. B. (2001). Enhancing learning: A matter of style or approach? Perspectives on thinking, learning, and cognitive styles (pp. 73-102). Lawrence Erlbaum Associates.

Bobkina, J., \& Stefanova, S. (2016). Literature and critical literacy pedagogy in the EFL classroom: Towards a model of teaching critical thinking skills. Studies in Second Language Learning and Teaching, 6(4), 677-696. https://doi.org/ 10.14746/ssllt.2016.6.4.6

Condelli, L., Wrigley, H., \& Yoon, K. S. (2009). “What works” for adult literacy students of English as a second language. In S. Reder, \& J. Bynner (Eds.), Tracking adult literacy and numeracy skills: Findingsfrom longitudinal research (pp. 132-159). Routledge.

Cooper, T. C. (2001). Foreign language style and personality. Foreign Language Annals, 34, 301- 316. https://doi. org/10.1111/j.1944-9720. 2001.tb02062.x

Davis, S. G., \& Gray, E. S. (2007). Going beyond test-taking strategies: building self-regulated students and teachers. Journal of Curriculum and Instruction, 1(1), 31-47. http://www.joci.ecu.edu/

Delfino, M., Dettori, G., \& Persico, D. (2010). An online course fostering self-regulation of trainee teachers. Psicothema, 22(2), 299-305. https://doi.org/10.3776/joci.2007.v1n1p31-47

Dembo, M. H. (2001). Learning to teach is not enough - Future teachers also need to learn howto learn. Teacher Education Quarterly, 28(4), 23-35.

Dewey, J. (1933). How we think: A restatement of the relation of reflective thinking to the educational process. Lexington.

Dignath, C. \& Büttner, G. (2018). Teachers' direct and indirect promotion of self- regulatedlearning in primary and secondary school mathematics classes - insights from video-based classroom observations and teacher interviews. Metacognition and Learning, 13(2), 127-157. https://doi.org/10.1007/s11409-018-9181-x

Elder, L., \& Paul, R. (2003). Critical thinking: Teaching students how to study and learn. Journal of Developmental Education, 27(1), 36-37.

Elias, F., Hamzah, M. I., \& Razak, K. A. (2019). Elements of thinking in teaching student-centered learning on faith: A case study. International Journal of Academic Research in Progressive Education and Development, 8(3), 126- 132. http://dx.doi.org/10.6007/IJARPED/v8- i3/6297

Ennis, R. (1996). Critical thinking dispositions: Their nature and assessability. Informal Logic, 18(2-3), 165-182.

Facione, N. C., \& Facione, P. A. (1996). Externalizing the critical thinking in knowledge development and critical judgment. Nursing Outlook, 44(3), 129-136. http://dx.doi.org/10.1016/S0029-6554(06)80005-9

Fasko, D. (2003). Critical thinking: Origins, historical development, future direction. In D. Fasko (Ed.), Critical thinking and reasoning: Current research, theory, and practice (pp.3-20). Hampton Press.

Faruji, L. F. (2012). Teachers' teaching styles at English language institutes in Iran. International Journal of Social Sciences and Education, 2(1), 364-373.

Fisher,A.(2001).Criticalthinking: Anintroduction. Cambridge University Press.

Flanders, A. (1970). Analyzing teacher behavior. Addition-Wesley Publishing Company.

Ghanizadeh, A. (2011). An investigation into the relationship between self-regulation and critical thinking among Iranian EFL teachers. The Journal of Technology \& Education, 5(3), 213- 221.

Ghanizadeh, A., \& Heydarnejad, T. (2015). A cross-contextual analysis of Iranian EFL teachers' attitudes and perceptions of critical thinking. International Journal of Research Studies in Education, 4(4), 27-38. http:// dx.doi.org/10.5861/ijrse.2015.1138

Giancarlo, C. A., \& Facione, P. A. (2001). A look across four years at the disposition toward critical thinking among undergraduate students. Journal of general education, 50(1), 29- 55. http://dx.doi.org/10.1353/ jge.2001.0004

Grasha, A. F. (1994). A matter of style: The teacher as expert, formal authority, personal model, facilitator, and delegator. College Teaching, 42(4), 142-49.

Grasha, A. F. (1996). Teaching with style: A practical guide to enhancing leaning by understanding teaching and learning style. Alliance Publishers.

Grasha, A. F. (2002). The dynamics of one-on-one teaching. College Teaching, 50(4), 139-146. http://dx.doi. org/10.1080/87567550209595895

Gurcay, D., \& Ferah, H. O. (2018). High school students' critical thinking related to their metacognitive selfregulation and physics self-efficacy beliefs. Journal of Education and Training Studies, 6(4), 125-130. https:// doi.org/10.11114/jets.v6i4.2980

Halonen, J. S. (1995). Demystifying critical thinking. Teaching of Psychology, 22, 75-81. https://doi.org/10.1207/ s15328023top2201_23

Heydarnejad, T., Hosseini Fatemi, A., \& Ghonsooly, B. (2017a). An exploration of EFL teachers' teaching styles and emotions. Journal of Applied Linguistics and Language Research, 4(2), 26-46. http://www.jallr.com 
Heydarnejad, T., Hosseini Fatemi, A., \& Ghonsooly, B. (2017b). Emotions and self-regulation: A case of Iranian EFL high school and private language institute teachers. International Journal of Educational Investigations, $4(4), 82-100$.

Heydarnejad, T., Ebrahimi, M. R., \& Najjari, H. (2018). On the associations among critical thinking, reflective thinking, and emotions: A case of Iranian EFL Teachers.International Journal of Applied Linguistics \& English Literature, 7(6), 97-103. http://dx.doi.org/10.7575/aiac.ijalel.v.7n.6p.97

Ivie, S. D. (2001). Metaphor: A model for teaching critical thinking. Contemporary Education, 72(1), 18-23.

Jarvis, P. (2004). Adult education and lifelong learning: Theory and practice. Routledge Falmer.

Jenkins, E. K. (1998). The significant role of critical thinking in predicting auditing students' performance. Journal of Education for Business, 73(5), 274 -279.

Karimnia,A., \& Mohammadi, N.(2019). The effects of teachers' gender, teaching experience, and brain dominance on their teaching styles. International Journal of Research in English Education, 4(1), 37-46. http://dx.doi. org/10.29252/IJREE.4.1.37

Kaplan, J., \& Kies, A. (1995). Teaching styles and learning styles: Which came first? Journal of Instructional Psychology, 22, 29-34.

Kavanoz, S., \& Akbaş S. (2017). EFL teachers' conceptualizations and instructional practices of critical thinking. International Online Journal of Education and Teaching, 4(4), 418-433. http://iojet.org/index.php/IOJET/ article/view/251/180

Keeley, B. T., Holland, J., \& Watson, M. (2005). Preliminary evidence on the association between critical thinking and performance in principles of accounting. Issues in Accounting Education, 20(1), 33-49. http://dx.doi. org/10.2308/iace.2005.20.1.33

Lowman, J. (1995). Mastering the techniques of teaching (2nd ed). San Francisco.

Mayfield, M. (2001). Thinking for yourself: Developing critical thinking skills through reading and writing $\left(5^{\text {th }}\right.$ ed.). Harcourt College.

Minnich, E. (1990). Transforming knowledge. Temple University Press.

Monshi Toussi, M. T., \& Ghanizadeh, A. (2012). A study of EFL teachers' locus of control and self-regulation and the moderating role of self-efficacy. Theory and Practice in Language Studies, 2(11), 2363-2371. http://dx.doi. org/10.4304/tpls.2.11.2363-2371

Nouraey, P., \& Karimnia, A. (2016). The impact of rhythm and gender on spelling output of Iranian EFL learners: A cross-sectional study. Khazar Journal of Humanities and Social Sciences, 19(2), 53-63. http://dx.doi. org/10.5782/2223-2621.2016.19.2.53

Paris, S. G., \& Winograd, P. (1999). The role of self-regulatedlearning in contextual teaching: Principles and practices forteacher preparation. In Contextual teaching andlearning: Preparing teachers to enhance student success inthe workplace and beyond (pp. 219-253). ERIC Clearinghouse on Adult, Career, and Vocational Education/ERIC Clearinghouse on Teaching andTeacher Education. https://files.eric.ed.gov/fulltext/ ED427263.pdf

Partovi, N., \& Tafazoli, D. (2016). On the relationship between Iranian EFL teachers' self-regulation, selfresiliency, gender and teaching experience. Educational Research, 4(1), 7- 25.

Pazhoman, H., \& Sarkhosh, M. (2019). The Relationship between Iranian English high school teachers' reflective practices, their self-regulation and teaching experience. International Journal of Instruction, 12(1), 995-1010. https://doi.org/10.29333/iji.2019.12164a

Peel, K. L. (2019). The fundamentals for self-regulated learning: A framework to guide analysis and reflection. Educational Practice and Theory, 41(1), 23-49. https://doi.org/10.7459/ept/41.1.03

Peel, K. L. (2020). Everyday classroom teaching practices for self-regulated learning. Issues in Educational Research, 30(1), 260-282. http://www.iier.org.au/iier30/2020conts.html

Phan, H. P. (2010). Critical thinking as a self-regulatory process component in teaching and learning. Psicothema, 22(2), 284-292.

Pintrich, P. R. (2000). The role of goal orientation in self-regulated learning. In M. Boekaerts, P.R. Pintrich, \& M. Zeidner (Eds.), Handbook of self-regulation (pp. 451-502). Academic.

Randi, J. (2004). Teachers as self-regulated learners. Teacher' College Record,106(9), 1825-1853. https://doi. org/10.1111/j.1467-9620.2004.00407.x

Renner, C. E. (1996). Enrich learners' language production through content-based instruction. Paper presentedat a National Conference on Lingua e Nuova Didattica, Modena, Italy. (ERIC Document Reproduction Service No. ED 411 694).

Reynolds, A. (1992). What Is Competent Beginning Teaching? A Review of the Literature. Review of Educational Research, 62, 1-35. https://doi.org/10.3102/00346543062001001 
Safari, E., \& Hejazi, M. (2017). Learning styles and self-regulation: An associational study on high school students in Iran. Mediterranean Journal of Social Sciences, 8(1), 463-469. https://doi.org/10.5901/mjss.2017. v8n1p463

Schunk, D. H, \& Zimmerman, B. J.(Eds.).(1994). Self-regulation oflearning and performance: Issues and educational applications. Lawrence Erlbaum Associates.

Scriven, M., \& Paul, R. (2004). The critical thinking community. http://www.criticalthinking.org/aboutCT/ definingCT.shtml

Serin, H. (2018). A Comparison of teacher-centered and student-centered approaches in educational settings. International Journal of Social Sciences \& Educational Studies, 5(1), 164-167. https://doi.org/10.23918/ijsses. v5i1p164

Shanker, S. (2016). Self-Reg: How to help your child (and you) break the stress cycle and successfully engage with life. Penguin Random House.

Skinner, B. F. (1974). About behavioralism. Random House.

Solomon, D., \& Kendall, A. J. (1979). Children in classrooms: An investigation of person environment interaction. Prager Publishers.

Tavakoli, M., \& Karimnia, A. (2017). Dominant and gender-specific tendencies in the use of discourse markers: Insights from EFL learners. World Journal of English Language, 7(2), 1-9. https://doi.org/10.5430/wjel.v7n2p1

Vardi, I. (2015). The relationship between self-regulation, personal epistemology, and becoming a critical thinker: Implications for pedagogy. In M. Davies \& R. Barnett (Eds.), The Palgrave handbook of critical thinking in higher education (pp. 193-197). Palgrave Macmillan.

Vaughn, L., \& Baker, R. (2001). Teaching in the medical setting: Balancing teaching styles learning styles and teaching methods. Medical Teacher, 23(6), 610- 612. https://doi.org/10.1080/01421590120091000

Watson, G. B., \& Glaser, E. M. (1980). WGCTA Watson-Glaser Critical Thinking Appraisal Manual: Forms A and B. The Psychological Corporation.

Watson G. B., \& Glaser, E. M. (2002). Watson-Glaser Critical Thinking Appraisal. Psychological Corporation.

Yesim, C. A., Sungur, S., \& Uzuntiryaki, E. (2009). Teacher self-regulation: Examining a multidimensional construct. Educational Psychology, 29(3), 345-356. https://doi.org/10.1080/01443410902927825

Zhang, H., Yuan, R., \& He, X. (2020). Investigating university EFL teachers' perceptions of critical thinking and its teaching: Voices from China. Asia-Pacific Education Researcher, 29(5), 483-493. https://doi.org/10.1007/ s40299-020-00500-6

Zimmerman, B. J., \& Risemberg, R. (1997). Self-regulatory dimensions of academic learning and motivation. In G.D. Phye (Ed.), Handbook of academic learning (pp. 105-125). Academic Press. http://dx.doi.org/10.1016/ B978-012554255-5/50005-3

Zimmerman, B. J. (2000). Attaining self-regulation: A social cognitive perspective. In M. Boekaerts, P.R. Pintrich, \& M. Zeidner (Eds.), Handbook of self-regulation (pp.13-39). Academic Press. https://doi.org/10.1016/B978012109890-2/50031-7

Zimmerman, B. J., Bonner, S., \& Kovach, R. (1996). Developing self-regulated learners: Beyond achievement to selfefficacy. American Psychological Association. https://doi.org/10.1037/10213-000 